\title{
The Innovativeness and Competitiveness of the Visegrad Group Countries in the years 2011-2016 - Selected Indicators
}

\author{
Anna KOWALSKA ${ }^{1}$, Jaroslav KOVÁRNÍK ${ }^{2}$ \\ ${ }^{1}$ Wroclaw University of Economics, Wroclaw, Poland \\ anna.kowalska@ue.wroc.pl \\ ${ }^{2}$ University of Hradec Králové, Hradec Králové, Czech Republic \\ jaroslav.kovarnik@uhk.cz
}

\begin{abstract}
Visegrad Group is a group of four countries in the Central Europe, namely of the Czech Republic, Slovakia, Poland, and Hungary. These countries share not only similar history, but also similar economic development and geopolitical ideas. Nowadays, the economic development of every country and its competitiveness on the world market is supported by the creation of innovation (knowledge-based economy). The aim of this article is to present the results of a comparative analysis of changes in innovativeness and competitiveness of V4 economies over a period of 5 years. The Summary Innovation Index (SII) was used in the European Innovation Scoreboard, as well as the Global Competitiveness Report and Global Competitiveness Index (GCI). The analysis shows that all members of V4 are so called moderate innovators; however, there are some differences among analyzed countries. The Czech Republic begins to diverge from other member states of V4 in terms of SII, and it has been increasing its GCI as well. Poland occupies one of the last positions in the V4 innovation ranking, where Hungary was the weakest in terms of competitiveness in 2016. Detail analysis of results is in this article.
\end{abstract}

Keywords: Competitiveness, Innovation, Visegrad Group.

\section{Introduction}

Innovativeness and competitiveness are frequently used terms in current globalized world. Both of them have been analyzed by many researchers in different points of view; see for example $[1,3,8,9]$. Despite this fact, there exist no universal definitions of these terms.

As far as innovativeness is concerned, it can be defined as an ability of the country to produce and commercialize goods and services by using new knowledge and skills. Knowledge is the most comprehensive resource of all those which help developing wealth. Knowledge is dynamic, since it is created in social interactions amongst individuals and organisations [6], for example the SECI Model refers to the system of knowledge acquisition and sharing [5]. Other definition claims that it focuses on 
potential of the country to create, improve and use innovations with the purpose of generating economic value. It is quite obvious that these definitions are not same, but they are very similar and both of them emphasize the fact that innovativeness supports economic growth of the country. Innovativeness can be measured by several different tools, where one of the relatively frequently used is the Summary Innovation Index (SII).

The phenomenon of competitiveness is even more confusing. In simple words, it can be explained as the effort of the country to be competitive on the world market [7, 12]. However, there is still no generally accepted definition of the competitiveness; moreover, some authors have an opinion that the concept of macro-competitiveness does not exist. In spite of the controversy behind the definition of competitiveness, it is estimated that there exist more than a hundred of different form of indicators for quantifying this phenomenon. One of them is Global Competitiveness Index (GCI).

The aim of this article is to assess the innovativeness and competitiveness of the economies of the Visegrad Group countries using the SII and GCI indicators and to show the changes that have taken place in this regard in 2011 - 2016. [1]

\section{Characteristics of the Visegrad Group countries}

Countries of Visegrad Group, or Visegrad Four, namely the Czech Republic, Slovakia, Hungary, and Poland, can be found in the Central Europe. These countries share similar history, where all of them were on the east side of the Iron Curtain, which means under the influence of the Soviet Union. All countries went through transformation in the nineties of last century, and all countries also joined the European Union together in 2004. Nowadays, these countries share some similar opinions, for example in the terms of migration crisis. Because of the common history, these countries established the Visegrad Group in 1991 and had been cooperating even before they joined the EU. After their entrance they still have been cooperating, with greater or lesser success, not only in general ways, but also on the field of EU.

Based on the fact that Poland has currently more than 38.4 million inhabitants, the Czech Republic around 10.5 million of inhabitants, Hungary around 9.8 million, and Slovakia around 5.4 million, and, it is quite obvious that the level of GDP in billions of euro is the highest in Poland, while the Czech Republic is on the second position, Hungary is the third, and Slovakia the fourth.

However, it is better to use the level of GDP per capita for mutual comparison. According to this, the highest level has the Czech Republic, Slovakia is on the second place, Poland is the third, and Hungary the last. With respect to this information is good to add one interesting fact. Even if the development in the number of inhabitants in each country has not been steady, this number grew in the Czech Republic and in Slovakia (comparison of the number of inhabitants in the years 2000 and 2016), while it dropped in Hungary and in Poland. [4]

Deep analysis of GDP development shows that in all analysed countries was significant decrease in this indicator in the year 2009 (both in absolute value and in 
per capita) as a result of global economic crisis. However, the after crisis development is different. The Czech Republic was growing between 2009 and 2011, it was decreasing between 2011 and 2014, and it has been growing again since 2014. It managed to exceed pre-crisis year in 2011. Poland was on the last position in 2008, it has been growing since 2009 to 2015, it exceeded pre-crisis year in 2011, but it exceeded Hungary in 2012. However, it has dropped in 2016, where Hungary has exceeded this country again. Hungary has been growing since 2009 with one exception in 2012. It was on the fourth position before crisis and it is on the fourth position again in 2016. Slovakia has been growing since 2009, and it also managed to exceed pre-crisis year within one year already in 2010. [4]

\section{Purpose, scope and methodology of research}

The aim of this article is to assess the innovativeness and competitiveness of the economies of the Visegrad Group countries using the SII and GCI indicators and to show the changes that have taken place in this regard in 2011-2016.

The European Innovation Scoreboard (EIS) reports and the Summary Innovation Index (SII) were used to analyse the innovativeness of the V4 economies. The SII was created to identify and analyse instruments affecting socio-economic cohesion policy. The Community Innovation Survey, Eurostat and the OECD were used to calculate the level of innovation. The SII consists of 27 indicators, divided into ten dimensions, i.e. human resources, attractive research, innovation-friendly environment, finance and support, companies, innovations, linkages, intellectual assets, employment impacts and economic effects. These dimensions are grouped into four groups: framework conditions, investments, innovation activities and impacts. The Summary Innovation Index was adopted as $0-1$, where 1 represents the highest level of innovation, while 0 is the lowest. [2]

The Global Competitiveness Report of the World Economic Forum (WEF) and the Global Competitiveness Index were used to analyse the competitiveness of the economies of the Visegrad Group. The current GCI methodology has been in use since 2007 and includes 114 indicators grouped into 12 pillars: institutions, infrastructure, macroeconomic environment, health and primary education, labor market efficiency, financial market development, technological readiness, market size, business sophistication, and innovation. The GCI methodology takes into account differences in the economic progress of the analysed countries. It identifies three stages of development: factor driven, efficiency-driven, and innovation-driven. Higher importance is given to the pillars of competitiveness, which are more important at a given stage of economic development of the country. This methodological approach is particularly important for countries with medium levels of economic development [11].

For the sake of clarity in some drawings and tables there were used symbols: for the Czech Republic (CZ), for Hungary (H), for Poland (PL), for Slovakia (SK). 


\section{$4 \quad$ Research results}

\subsection{Innovativeness of the Visegrad Group economies in the years 2011- 2016 - indicator SII}

The summary innovation index for all Visegrad countries was in the years 2011-2016 below the EU average. The average value was set at 100\% (fig 1). All V4 countries belonged to the so-called moderate innovators. In the analyzed years, the highest values among the Visegrad Group countries were obtained the Czech Republic. In its case, the value of the index in 2016 was at the level of $84.4 \%$ and despite the decrease (compared with 2011 by 5.3 points) it was still the highest in comparison with other V4 countries. Poland, despite an increase in the index in 2.6 years by $2.6 \mathrm{pp}$ (in 2016 $54.8 \%$ ) took the last place.

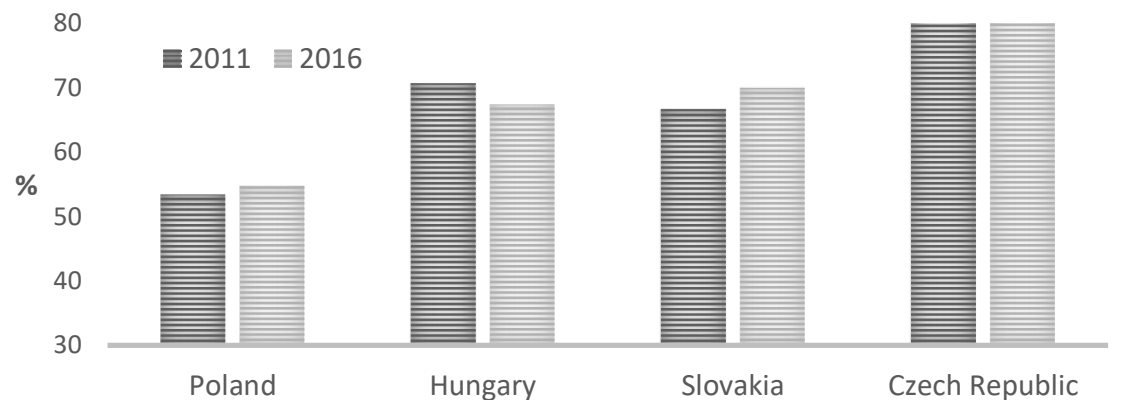

Fig. 1. Performance of V4 innovation systems in 2011 and 2016 [\%], [2]

Analysis of V4 innovation data, broken down into 4 groups of indicators, showed both: differences in innovation level between these countries and significant changes over five years (table 1).

Table 1. Innovativeness ranking by four thematic groups EU and V4 in 2016 as compared to 2011 [points] [2]

\begin{tabular}{|l|c|c|c|c|c|c|c|c|c|c|c|c|}
\hline \multirow{2}{*}{$\begin{array}{c}\text { Country } \\
\text { symbol }\end{array}$} & \multicolumn{3}{|c|}{$\begin{array}{c}\text { Framework } \\
\text { conditions }\end{array}$} & \multicolumn{3}{|c|}{ Investments } & \multicolumn{3}{c|}{$\begin{array}{c}\text { Innovation } \\
\text { activities }\end{array}$} & \multicolumn{4}{c|}{ Impacts } \\
\cline { 2 - 16 } & 2011 & 2016 & change & 2011 & 2016 & change & 2011 & 2016 & change & 2011 & 2016 & change \\
\hline CZ & 0.29 & 0.38 & 0.09 & 0.55 & 0.44 & -0.11 & 0.41 & 0.34 & -0.07 & 0.64 & 0.56 & -0.08 \\
\hline SK & 0.30 & 0.30 & 0.00 & 0.25 & 0.36 & 0.11 & 0.23 & 0.22 & -0.01 & 0.62 & 0.64 & 0.02 \\
\hline H & 0.26 & 0.30 & 0.04 & 0.27 & 0.29 & 0.02 & 0.27 & 0.20 & -0.07 & 0.71 & 0.66 & -0.05 \\
\hline PL & 0.19 & 0.27 & 0.08 & 0.29 & 0.30 & 0.01 & 0.21 & 0.18 & -0.03 & 0.47 & 0.41 & -0.06 \\
\hline
\end{tabular}

The Czech Republic in 2016 also reached the highest values in three of the four thematic groups, i.e. framework conditions ( 0.38 points), investments ( 0.44 points) and innovation activities ( 0.34 points). The weakest in this respect was Poland, which 
in the three groups got the lowest values, while in the fourth it overtook Hungary with only one point.

Despite the fact that the Czech Republic has reached the highest position among the V4 countries and the majority of the thematic groups during the period under review, some of them are deteriorating. In the case of three of the four thematic groups, the value of the index fell, i.e. investments (by 20\%), innovation activities (by $17.1 \%$ ) and impacts (by 12.5\%). The remaining V4 countries did not record a fall in the value of the index in the area of investments. The largest increase was recorded in Slovakia (by 44\%). In the case of the Czech Republic, the value of the indicator in the framework conditions group increased (by $31 \%$ ). Poland $(42.1 \%)$ and Hungary $(15 \%)$ also recorded an increase in this figure, while Slovakia maintained its 2011 value. Among all countries in the Visegrad Group, the index in the innovation activities group decreased. The greatest decline was recorded, the memory already, the Czech Republic and Hungary. In the last group, the highest value of the index in 2016, despite its fall of 7\%, was Hungary (66 points). Poland (12.8\%) and Czech Republic $(12.5 \%)$ also recorded a decrease. In the case of Slovakia there was an increase in its value (by $3.2 \%$ ).

The dimensions of the SII in the V4 countries were also analysed (fig. 2). In the framework conditions group in 2016, the highest values in all three dimensions were obtained by the Czech Republic. The country raised the value of human resources and attractive research systems by 9 points ( 0.39 points and 0.33 points respectively) and innovation-friendly environment by 8 points (41 points). In the case of the human resources dimension Poland and Hungary have grown, although not as large as in the case of the Czech Republic. Slovakia has reduced the value of this dimension (by 5 points). In spite of this great fall, Slovakia was in second place with 0.38 points (just behind the Czech Republic). The lowest value was Hungary. Attractive growth systems, although not as impressive as in the case of the Czech Republic, gained Slovakia (by 2 points) and Poland (by 3 points), while the decrease (by 1 point) was recorded by Hungary. The increase in the value of this dimension in the case of Poland did not change its weakest position among the V4 countries. In the context of the innovation-friendly environment, all V4 countries have increased the value of the index. The highest (by 17 points) was recorded by Poland, which in this way lost in Slovakia.

In the investment group, the high values of the index in the finance and support sector recorded in 2016, just behind the Czech Republic (0.44 points), Slovakia (0.41 points). The increase in this indicator, compared to 2011, was the highest for this country (by 28 points). Only Czech Republic recorded a decrease in this dimension, but this did not affect the leader's position in this dimension. Also in the dimension of investment companies the highest value of the index was obtained in 2016 (despite a decrease compared to 2011 - by 2 points) Czech Republic (0.44 points). The biggest increase (by 3 points) of this dimension was obtained by Hungary, which gave them 34 points. The weakest result, despite 1 point of growth, gained in this dimension Poland. 


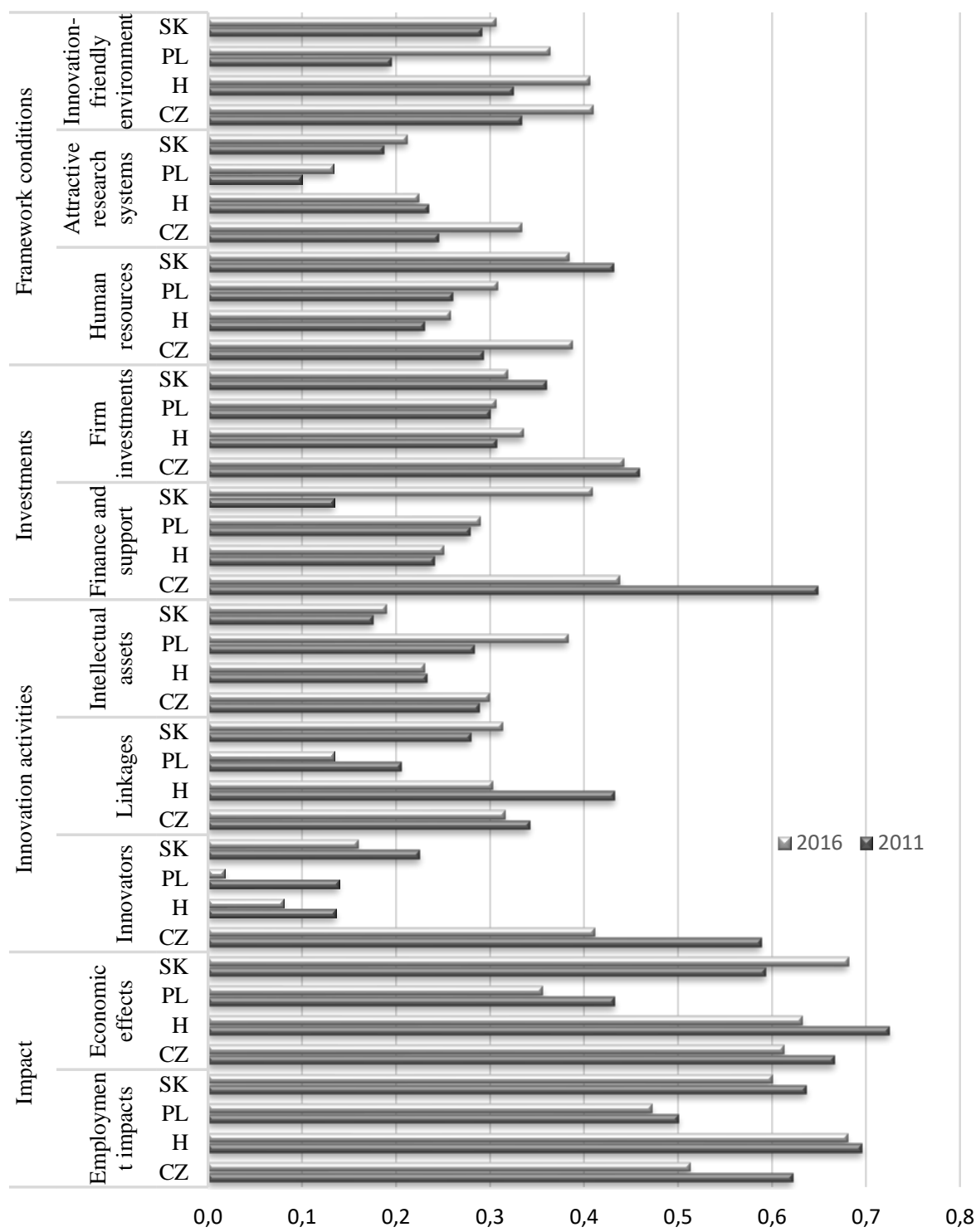

Fig. 2. The dimension of innovation belonging to four thematic groups in V4 countries in 2011 and 2016 [points] [2]

The next group of SII is innovation activities. This group includes the innovations which in the analysed years, in all the V4 countries, recorded a decline in the value of the index. The biggest decrease in this dimension (by 18 points) was obtained by the Czech Republic. In the case of Poland, the value of this dimension decreased by 12 points in the analysed period. This resulted in Poland obtaining only 0.02 points in this dimension and the last position among the Visegrad Group countries. Also in the 
2016 linkages there has been a decline in the value of the index, in three of the four V4 countries. The largest decrease was in Hungary (by 13 points), followed by Poland (by 7 points). The drop in the value of this dimension in the case of Poland kept it at the last position among the V4 countries. On the other hand, a slight increase in the value of this dimension by Slovakia (by 3 points) allowed it to rank in front of Hungary. The last dimension in this group is the intellectual assets. The highest value in this dimension in 2016 was obtained by Poland. The first place gave it a 10 point increase in its value compared to 2011. The value of the index at the level of 38 points allowed Poland to overtake (by 8 points) the Czech Republic. Other countries such as the Czech Republic and Slovakia recorded a slight increase in this period (by 1 point) or in the case of Hungary remained at the same level.

The last thematic group influencing the SII is impacts, which include two dimensions: employment impacts and economic effects. In terms of employment impacts in 2016, all Visegrad Group countries recorded a decline in value relative to 2011. The Czech Republic lost the most significant share (by 11 points). For other countries, the falls were lower (at 2-4 points). The highest values of this dimension were recorded in Hungary in 2016. Slovakia was second. The decline of this indicator in the case of the Czech Republic has caused the country to remain in the third position just before Poland. In the case of economic effects, in 2016, the highest values at 0.68 points were obtained by Slovakia. This country is the only country that has seen growth (by 9 points). This caused Slovakia to move from rank 3 to 1 . The remaining V4 countries, between 2011 and 2016, saw a decline in value of this dimension. The biggest fall was in Hungary ( 9 points) and then in Poland (by 8 points). However, this did not affect Poland's position in the ranking. The country is in this dimension still occupies the last place among the V4 countries.

\subsection{Competitiveness of the Visegrad Group economies in the years 2011-2016 - GCI indicator}

The Global Competitiveness Report from 2015-2016 located The Visegrad Group in two different groups: Advanced Economies - Czech Republic and Slovakia and Emerging and Developing Europe - Poland and Hungary [11].

In the years 2015-2016, the highest value of the GCI index among the V4 countries was noted by the Czech Republic. In the case of this country the index increased by 0.12 points compering to 2011 (fig. 3). The remaining countries decreased their value, in the analysed period, in turn: Poland - by 0.02 points and Hungary - by 0.11 points. Slovakia maintained its value at the same level. 


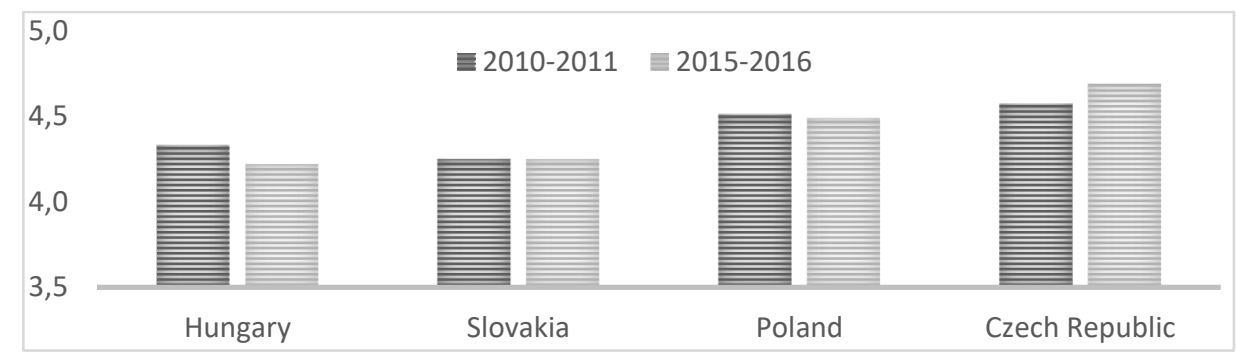

Fig. 3. Global Competitiveness Index in V4 countries in 2010-2011 and 2015-2016 [points], $[10,11]$

The analysis of the competitiveness data of the V4 economies, broken down by 3 groups of indicators, showed differences in the level of competitiveness between these countries and the changes that occurred during the period under examination (table 2).

Table 2. The competitiveness index in V4 country by three subindexes in 2015-2016 as compared to 2010-2011 [points], [10, 11]

\begin{tabular}{|l|c|c|c|c|c|c|c|c|c|}
\hline \multirow{2}{*}{$\begin{array}{c}\text { Country } \\
\text { symbol }\end{array}$} & \multicolumn{3}{|c|}{ Basic requirements } & \multicolumn{3}{c|}{ Efficiency enhancers } & \multicolumn{3}{|c|}{ Innovation and sophistication } \\
& $\begin{array}{l}2010- \\
2011\end{array}$ & $\begin{array}{c}2015- \\
2016\end{array}$ & Change & $\begin{array}{c}2010- \\
2011\end{array}$ & $\begin{array}{c}2015- \\
2016\end{array}$ & Change & $\begin{array}{c}2010- \\
2011\end{array}$ & $\begin{array}{c}2015- \\
2016\end{array}$ & Change \\
\hline CZ & 4.91 & 5.27 & 0.36 & 4.66 & 4.78 & 0.12 & 4.19 & 4.14 & -0.05 \\
\hline SK & 4.77 & 4.73 & -0.04 & 4.43 & 4.34 & -0.09 & 3.54 & 3.68 & 0.14 \\
\hline H & 4.65 & 4.67 & 0.02 & 4.38 & 4.31 & -0.07 & 3.71 & 3.57 & -0.14 \\
\hline PL & 4.69 & 4.91 & 0.22 & 4.62 & 4.64 & 0.02 & 3.76 & 3.70 & -0.06 \\
\hline
\end{tabular}

The Czech Republic, in comparison with the other V4 countries, achieved the highest index values in the years 2010-2016, in all subindexes, i.e. basic requirements (5.27 points), efficiency enhancers (4.78 points) and innovation and sophistication factors (4.14 points). The lowest in all three subindexes in 2015-2016, were Hungary.

Analysis of subindexes in V4 showed that the Czech Republic increased the index value in subindexes "basic requirements" by more than $7 \%$ and "efficiency enhancers" by $2.6 \%$. It dropped in subindex "innovation and sophistication factors" (by $1.2 \%$ ). In the subindex basic requirements, Poland (4.7\%) and Hungary $(4.3 \%)$ also recorded an increase in value. In the case of Slovakia, its value decreased and amounted to 4.73 points. Despite the fact that it was the only decrease in V4, it still had higher value than Hungary. In the case of subindex "efficiency enhancers", the increase in the indicator value, apart from the already mentioned Czech Republic, was also noted by Poland, although its growth was insignificant (by $0.4 \%$ ). Slovakia and Hungary have reported a decrease in the index value in this subindex.

In the last subindex "innovation and sophistication factors" only Slovakia, in the period under examination, gained an index increase. An increase of $4 \%$ allowed Slovakia to move up in ranking in the third position. The remaining countries 
recorded a decrease in the value of this indicator, the largest in the case of Hungary (by $3.8 \%$ ). There were also analysed twelve pillars included in the three abovediscussed subindexes (fig. 4).

There are four pillars in the first subindex, which is called basic requirements: institutions, infrastructure, macroeconomic environment and health and primary education. In the institutions pillar, the highest values in the years 2015-2016 get Hungary. The increase in the value of the index by $13.2 \%$, compared to the years 2010-211, caused the country to move to the first position. The Czech Republic also recorded growth (by 5.1\%). The other countries have decreased the value of the index in this pillar, the largest in the case of Slovakia (by 5.6\%). In infrastructure most countries have reported an increase in the index value. The largest was in Poland $(13.2 \%)$. Hungary and Slovakia increased the index in this pillar at a similar level (in turn $2.3 \%$ and $2.4 \%$ ). The $2.1 \%$ decrease was recorded by the Czech Republic. In the macroeconomic environment, the V4 countries have not reduced the value of the indexes obtained in 2010-2011. The Czech Republic grew by $22.4 \%$, followed by Poland (by $8.5 \%$ ) and Hungary (by 6.5\%). Slovakia kept the index unchanged. The last pillar of the discussed subindex is health and primary education. In this pillar only the Czech Republic increased the value of the indicator (by 3.3\%). The value of the index at the same level was maintained by Poland (6.1 points). Indexes decreased only in Hungary and in Slovakia (by $3.4 \%$ and by $1.6 \%$ respectively).

Subindex efficiency enhancers include six pillars: higher education and training, goods market efficiency, labor market efficiency, financial market development, technological readiness and market size. In the higher education and training pillar in the years 2015-2016, the Czech Republic and Poland recorded 5.1 points, of which Poland increased by $2 \%$, while the Czech Republic maintained its level from 20102011. The largest increase in the index was recorded in Slovakia (by 2.2\%). Hungary, as the only one among the V4 countries, saw a drop in its value (by $4.2 \%$ ). In the pillar of goods market efficiency, in none of the countries discussed there was no decrease in the index. Most countries, i.e. Poland, Slovakia and Hungary, recorded growth (at $2.3-2.4 \%$ ). The Czech Republic maintained its unchanged position. All the countries in question reduced the value of the indicator in the labor market efficiency index compared to the years 2010-2011. The biggest drop of $17 \%$ was recorded by Slovakia.

This country lost the first position, which it held in 2010-2011 together with the Czech Republic. A large decrease also recorded Poland (by 10.9\%), Hungary (by 6.4\%) and the Czech Republic (by 6.7\%). In the case of the pillar of financial market development most of the V4 countries, i.e. Poland, Hungary and Slovakia, recorded a decline in the value of indices. This caused, that Poland lose its leading position (drop by $8.5 \%$ ). All V4 countries recorded an increase in index values in the technological readiness pillar. The Czech Republic and Poland achieved the highest growth rate of $20 \%$. In the last pillar of the market size, most countries in the period under review maintained the 2010-2011 index values. The increase, at the level of $2 \%$, was recorded only by Poland. 


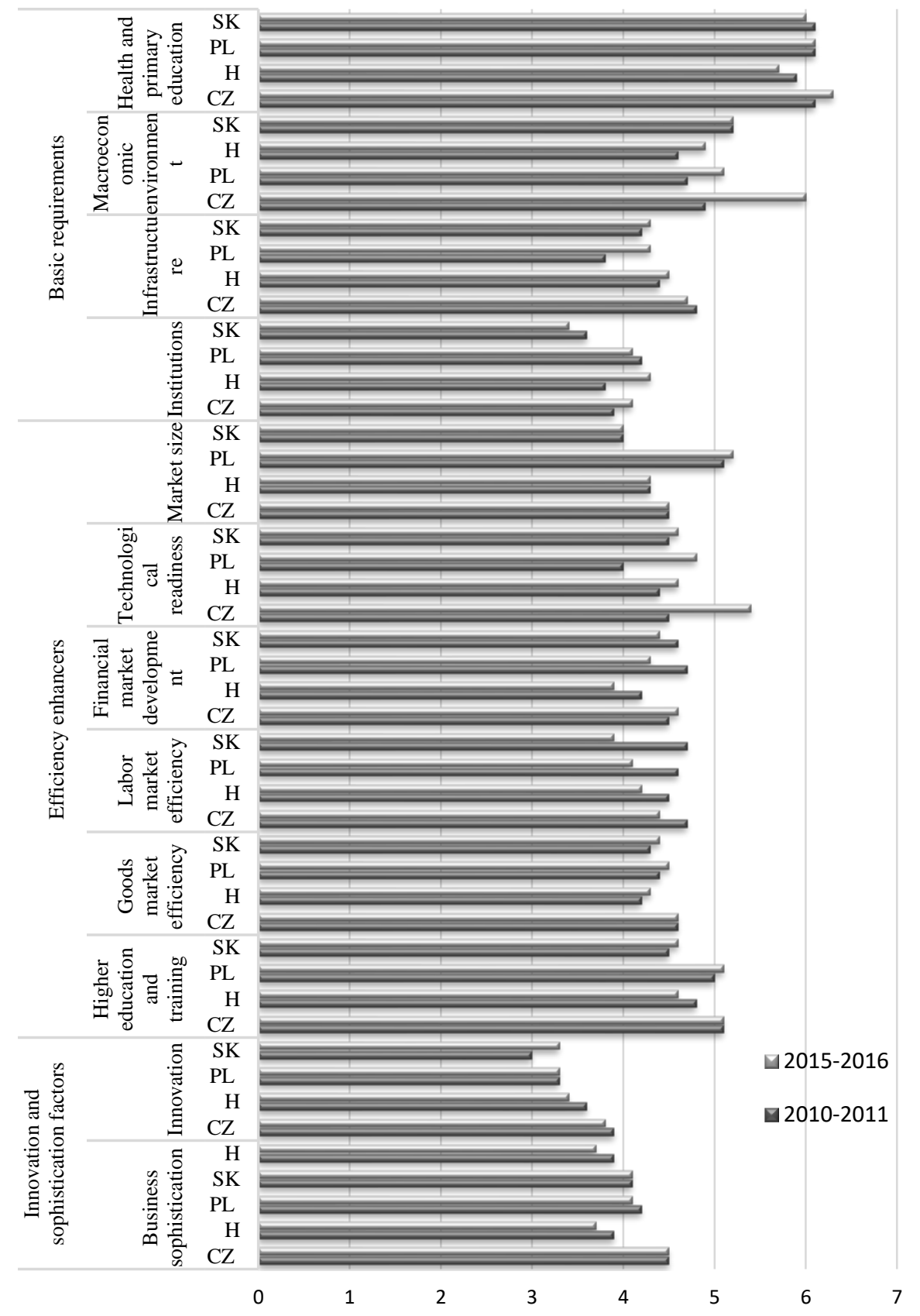

Fig.4. The competitiveness pillars belonging to the three thematic groups in the V4 countries in 2010-2011 and 2015-2016 [points], [10, 11] 
The latest subindex is innovation and sophistication factors, which include two pillars: innovation and business sophistication. In the case of pillar innovation, only Slovakia recorded a growth of $10 \%$. In Poland this indicator has not changed, but in other countries indicates decreased its value, i.e. Czech Republic (o 2.6\%) and Hungary (5.6\%). The second and last pillar is business sophistication. The highest values for this pillar in 2015-2016 were obtained by the Czech Republic (4.5 points), followed by Poland and Slovakia (4.1 points). Both the Czech Republic and Slovakia have not changed the value of this indicator from 2010-2011. Hungary and Poland recorded a decrease, respectively of $5.1 \%$ and $2.4 \%$.

\section{Conclusion}

The article analyses innovation and competitiveness indicators of the V4 economies. On the basis of the comparison of these countries' indices, it can be seen that they differ both in terms of innovation and competitiveness.

Now, in terms of innovation, all V4 countries belong to the so-called moderate innovators. SII values obtained by these countries are within the range of 50-90\% of the EU average. The results from the European Innovation Scoreboard reports from the years 2011-2016 show, however, an increasing gap in the level of innovation between these countries.

The analysis shows that the Czech Republic begins to diverge more and more in terms of the Summary Innovation Index from the other V4 countries. This country is starting to catch up with the so-called innovation followers. Poland is moving towards the group so-called catching-up countries. Poland occupies one of the last positions in the V4 innovation ranking for most thematic groups. The weakest results are obtained by the innovators dimension.

The competitiveness analysis of the V4 economies showed a significant difference between the surveyed countries. The Czech Republic, which is increasing its GCI index year by year, is the most competitive and innovative. In terms of competitiveness, Hungary was the weakest in 2016, which has even worsened in the period under review. Slovakia is trying to keep its value unchanged.

At present, the economic development of a given country is dependent on intangible factors related to knowledge. The transfer of knowledge contributes to a better use of available material resources in a given country. This is especially true in the Czech Republic, where knowledge dimensions are higher than in other V4 countries. Certainly, financial resources are needed to implement innovative solutions. Countries that are able to properly use their EU grants will improve their position. It is important for the V4 countries to look into their economies and translate them into innovative solutions. Only the development of the right strategy, which the Czech Republic is sure to accomplish, will allow the rest of the Visegrad Group to succeed and join the economies of the old European Union in terms of competitiveness and innovation. 


\section{References}

1. Despottović, D., Cvetanović, S., Nedić, V: Innovativeness and Competitiveness of the Western Balkan Countries and Selected EU Member States. Industrija 42(1), 27-45 (2014), DOI: $10.5937 /$ industrija42-4602.

2. European Innovation Scoreboard (EIS) 2011-2016, http://ec.europa.eu/DocsRoom/ documents/24829, last accessed 2017/10/10.

3. Gibson, D.V., Naquin, H.: Investing in Innovation to Enable Global Competitiveness: The Case of Portugal. Technological Forecasting \& Social Change 78(1), 1299-1309 (2011), DOI: 10.1016/j.techfore.2011.04.004.

4. GDP and Main Components, http://ec.europa.eu/eurostat/web/national-accounts/data /database, last accessed 2017/11/02.

5. Grzybowska, K., Gajdzik, B.: SECI model and facilitation on change management in metallurgical enterprise. Metalurgija 52(2), 275-278 (2013).

6. Grzybowska, K., Łupicka, A.: Knowledge Acquisition in Complex Systems. In: Yue, X.G., Duarte, N.J.R. (eds.) Proceedings of the 2016 International Conference on Economics and Management Innovations, vol. 57, pp. 262-266. Atlantis Press, Netherlands (2016), DOI: 10.2991/icemi-16.2016.5.

7. Kowalska, A.: Międzynarodowa konkurencyjność polskiego sektora owocowego po przystąpieniu do Unii Europejskiej. Zeszyty Naukowe Szkoły Głównej Gospodarstwa Wiejskiego w Warszawie. Problemy Rolnictwa Światowego 16(2), 176-185 (2016).

8. Olszańska, A., Piwowar, A., Olszańska, M.: Size and Seasonality of Buying of Pigs for Slaughter in the Countries of the Visegrad Group (2005-2015). In: Jedlička, P., Marešová, P., Soukal, I. (eds.) Hradec Economic Days, vo. 7(1), pp. 652-661, University of Hradec Králové, Czech Republic (2017).

9. Özcelik, E., Taymaz, E.: Does Innovativeness Matter for International Competitiveness in Developing Countries? The Case of Turkish Manufacturing Industries. Research Policy 33(1), 409-424 (2004), DOI: 10.1016/j.respol.2003.09.011.

10. Schwab, K.: The Global Competitiveness Report 2015-2016. $1^{\text {st }}$ ed. World Economic Forum, Geneva (2015).

11. Schwab, K.: The Global Competitiveness Report 2010-2011. $1^{\text {st }}$ ed. World Economic Forum, Geneva (2010).

12. Tarnowska, A.: Konkurencyjność podażowa polskiego sektora warzywniczego w Unii Europejskiej. Economics of the 21st century, 3(3) 23-35 (2014), DOI: 10.15611/e21.2014.3.02. 